\title{
Design and Improvement of foundation soil for high-rise construction
}

\author{
Kwa Sally Fahmi ${ }^{1, *}$, Mohammed Y. Fattah ${ }^{2}$ and Andrey Pustovgar ${ }^{3}$ \\ ${ }^{1}$ Peter the Great St.Petersburg Polytechnic University, Polytechnicheskaya, 29, St. Petersburg, \\ 195251, Russia \\ ${ }^{2}$ University of Technology, Baghdad, Iraq. \\ ${ }^{3}$ Moscow State University of Civil Engineering, Yaroslavskoe shosse, 26, Moscow, 129337, \\ Russia
}

\begin{abstract}
The assessments were made in the current practice based on the design foundation of high-rise buildings in Moscow to find a method for improving the soil foundation. Many references showed that the current design was controlled by structural engineers. They commonly used the old methods of analysis, the first part was carried out for the design of the structure and architecture of high-rise building, the second part of the study was to explore the benefit of adopting the application of stone columns raft foundation design concept. A comparative study was made between the results of the 3-dimensional finite element (3D FEM) analysis in SCAD software. The results showed that the plate foundation of the building does not satisfy to carry the total load without some meaning of improvement. The 3D FEM by PLAXIS 3D showed that the used stone columns decreased the settlement because about $70-80 \%$ of the total building loads were carried by columns when the raft was placed in the stiff clay layer. The number of columns in the raft foundation can be significantly reduced, particularly if the soil had strong characteristics. The raft foundation settlement can be significantly reduced, particularly if the soil had strong characteristics.
\end{abstract}

\section{Introduction}

Moscow, the capital city of Russian, has been testifying a rapid increase in a number of high-rise buildings constructed for the past two decades. The buildings need to be based on raft foundations to transfer the loads to soil layers at depth. Typically, the tall buildings in Moscow require basements for the purpose of car park space which is specified by law. Therefore, the foundations are improved with stone columns at depths of 10-20 m below the ground surface, and often large numbers of columns located at closer spacing are utilized owing to big building loads on relatively small areas. The design has traditionally followed (piled foundation) concept for which all building loads are carried by piles. This traditional foundation design concept in Moscow was justified when considering the

\footnotetext{
*Corresponding author: kwasally93@gmail.com
} 
predilection of minimizing building settlement also the potential gap formation underneath the pile cap in long-term resulted from subsidence phenomenon caused by deep well pumping for groundwater outfit (Mirsayapov and Koroleva, 2016).

However, the reduction measures of Moscow descent have been much improved; consequently, the annual rate of descent in the city areas where there is more tall building development has been much even ceased or reduced.

It may be no longer a sag design approach by the ignoring the soil bearing resistance below the big-area pile cap in the design. Nowadays, the "piled raft foundation" is being adopted in design of tall buildings in many parts of the world and increasingly advocated (Mirsayapov and Koroleva, 2011; 2012 Fattah et al., 2013, 2015) because it has a potential and a better control of the differential settlement. The design makes use of the soil bearing resistance below the raft together with the load carrying capacity of piles. To ensure continuity of a soil bearing resistance of the raft, the piles are designed at a lower safety factor than that normally in the traditional plate foundation design so that settlement of the pile is enough to ensure the consistent contact between soil and raft. The value of settlement must be within a acceptable limit of building function and structural safety. With the advance in numerical analysis and tools, it is the objective of this study to design a building with 20 stories, to investigate the settlement in the foundation and to study the benefit of adopting the piled raft foundation concept for foundation design of the tall buildings in Moscow.

Nguyen and Kim (2013) suggested a design method which takes into account interaction effects for PRF. The raft was modeled as a plate supported by a group of piles and soil, the maximum load resistance of the pile group is considered in computing the settlement when the vertical load was applied. Step by step approach was developed in the method for calculating the settlement and for determining the distribution of bending moment in the raft. Piled raft analysis using Plaxis 3D software utilizing the outputs from the proposed approach was performed. The results were verified against the experimental results of $4 \times 4$ and $3 \times 3$ piled raft model of different length embedded in homogenous silica sand using centrifuge accelerator. Good agreement was obtained when both experimental and numerical results were compared.

In the current paper, firstly the current design structure of the building is studied by using Software SCAD and design practice of piled foundation of tall buildings is made in the software CROSS. An investigation of the application of piled raft foundation in Moscow area and a 3D FEM analysis via using PLAXIS 3D Foundation software are done. The main idea for using stone column is to reduce the total cost in comparison with using of pile without affecting the performance of the resistance.

\section{Structural Design of the Building}

The block comprises of 20 floors where the main load bearing members are columns, walls and slabs as shown in Figures 1,2 and 3. The calculation model of the building for finite element structural analysis was created by using the software SCAD.

The test building has a frame-wall system, made from reinforced concrete and has the following parameters: total height of $90.9 \mathrm{~m}$ (20 floors); number of underground floors is 4; depth of laying the foundation - $15.15 \mathrm{~m}$; columns, underground part inner and outer walls are made with the use of concrete class B 40, stair wells and marches - B 25; providing load transfer from the over ground part to underground; the thickness of the foundation plate is $500 \mathrm{~mm}$. The columns were modeled as bars while walls and slabs are modeled as plates. The final calculation model consists of 180512 nodes and 201532 elements. 
The model was subjected to the following loads:

1. dead load

2. payload

3. weight of walling

4. weight of roof

5. weight of floors

6. weight of stairs

7. snow load

8. wind load
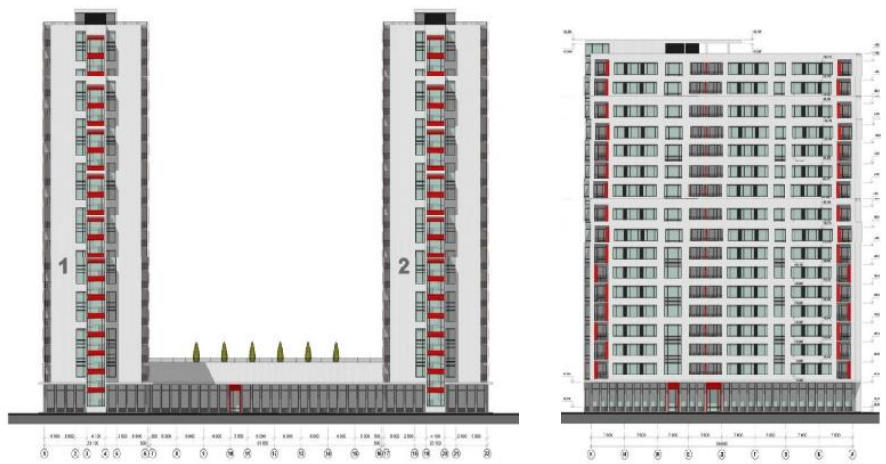

Fig. 1 View of the building.
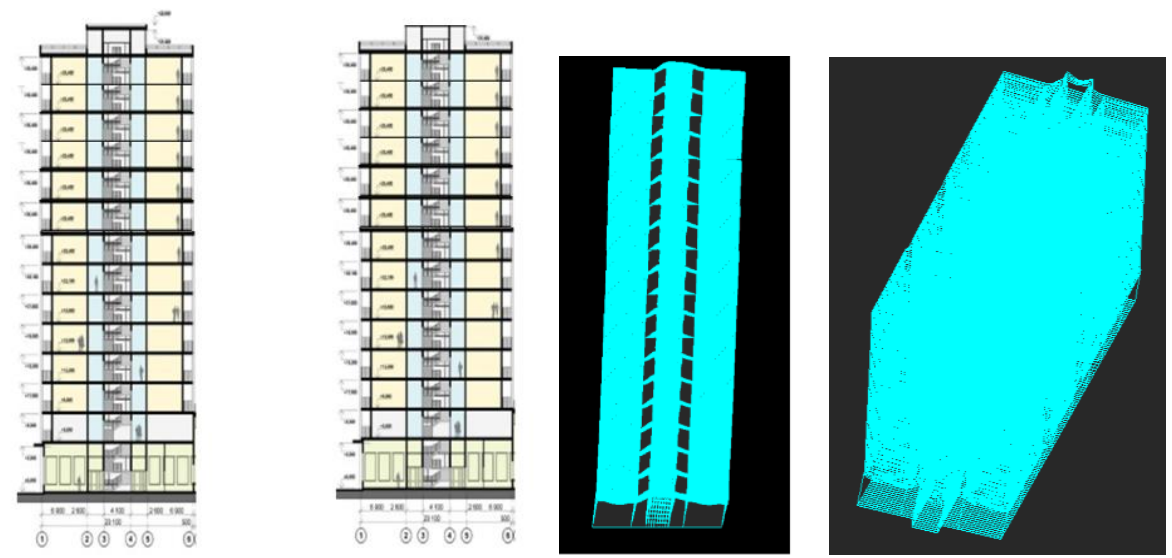

Fig. 2 The graphic form of displacement under loading combination
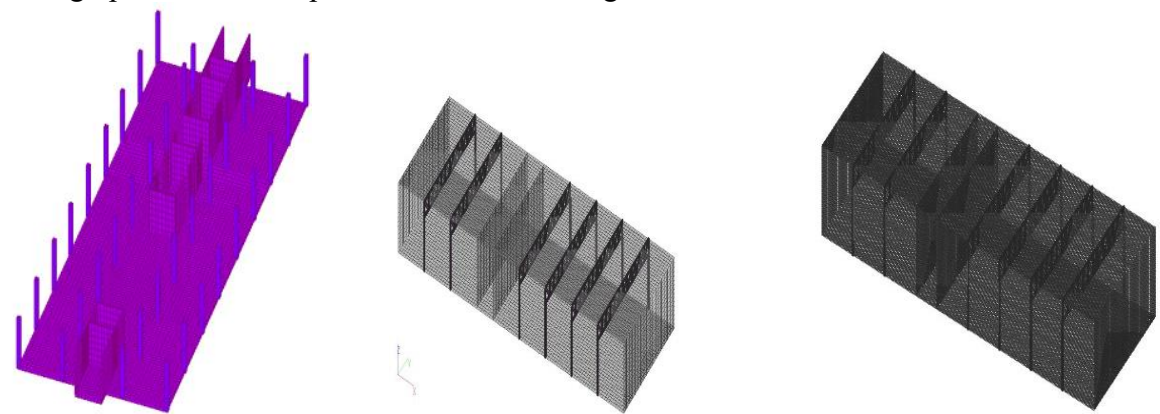

Fig. 3 The general mesh for the second part. 


\section{Displacement Analysis}

The issue of FEM is an approximation of real solution that depends on dimensions finite elements. In this project, the Schwartzman method is used for receiving measurement error of approximate solution for each calculation model. It is a method used to consider what is the size of finite element is better to use for getting more accurate results. Figure 4 shows the calculation of displacement by Schwartzman method.

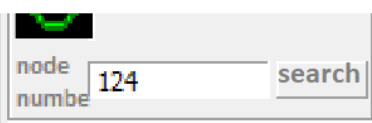

Coordinate

$\mathrm { X } \longdiv { 0 , 9 0 6 7 4 }$ M

Y $\longdiv { 1 , 8 0 9 1 3 }$ M

$2 \longdiv { 8 , 2 9 9 8 }$ M

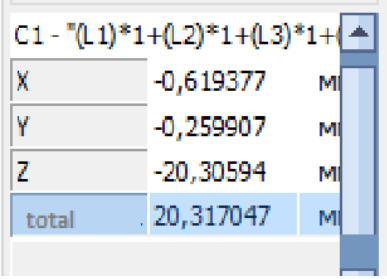

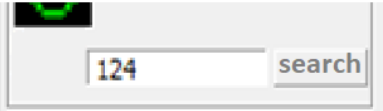

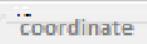

$\mathrm{X} 8,9067445$

Y 1,8091276

$2 \longdiv { 8 , 2 9 9 8 }$

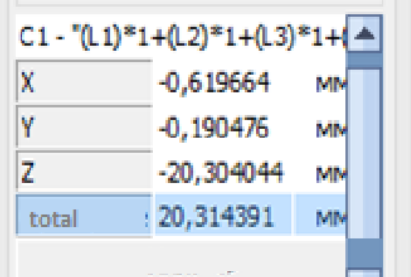

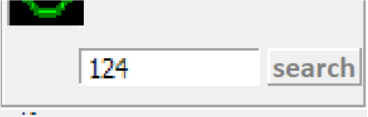

coordinate

$\mathrm{X} \quad 0,957$

Y 1,839

7,3

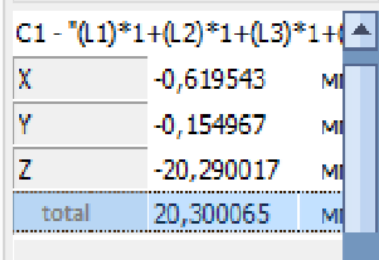

Fig. 4 Displacement analysis.

The result from SCAD software are listed below:

$Z_{n}=20,3 \mathrm{~mm}$

$Z_{n+1}=20.314 \mathrm{~mm}$

$Z_{n+2}=20.317 \mathrm{~mm}$

$$
\begin{gathered}
D_{n}=\frac{Z_{n+1} \quad Z_{n}}{Z_{n+2} \quad Z_{n+1}}=\frac{20,31420,3}{20,31720,314}=4,6667 \\
A_{n}=Z_{n+2}+\frac{Z_{n+2} \quad Z_{n}}{Z_{n+2} Z_{n+1}}=20,317 \mathrm{~mm} \\
R_{n}=Z_{n+2}+\frac{Z_{n+2} \quad Z_{n+1}}{D_{n} \quad 1}=\frac{20,31720,314}{4,666 \quad 1}+20,318=20,318 \mathrm{~mm} \\
S_{n}=\frac{1}{2}\left(A_{n}+R_{n}\right)=20,3175 \mathrm{~mm}
\end{gathered}
$$




$$
\begin{aligned}
& \Delta_{0.5}=\frac{S_{n} \quad Z_{n}}{S_{n}} * 100 \%=0.08 \% \\
& \Delta_{0.25}=\frac{S_{n} \quad Z_{n+1}}{S_{n}} * 100 \%=0.01 \% \\
& \Delta_{0.125}=\frac{S_{n} \quad Z_{n+2}}{S_{n}} * 100 \%=0.02 \%
\end{aligned}
$$

where :

$\mathrm{Z}$ : The size of finit element method,

$D_{n}$ : Displacement,

$A_{n} R_{n} S_{n}$ : Factors for calculate the errors, and

$\Delta_{0.5}$ : Error percentage .

According to the results of calculation, the model where the finite element dimension is $0.125 \mathrm{~m}$ has the smallest measurement error.

\section{Settlement Analysis}

The software CROSS is used to calculate the coefficients of subgrade (soil) reaction to analyze the substructures on elastic foundation (Winkler foundation), by using techniques of modelling a behaviour of a multi-layered soil body. It was assumed that the building of the problem may be of arbitrary type, and it is to be found in the course of site investigations. The analysis technique is based on a method of sagging analysis that uses a multilayer summing with a structural strength of the soil taken into consideration. This method has been suggested by Fedorovsky ((NIIOSP) (2010).

The subject of sight is a construction site where a designed structure is to be erected and other objects may also be found in the existing buildings or excavations that can influence the structure of benefit in the sense that loadings upon the soil caused by these objects may initiate sagging of the designed foundation structure. Also, it is assumed that results of site investigations are known, represented as data regarding soil properties in bored wells graphical interactive tools of the software provided for creating any structural configurations on the construction site. Information that describes bored wells and soil properties enable you to build a section of a soil body on your screen. Results of the computation are values of soil reaction coefficients at any point of the foundation of the structure that is being designed.

\section{Design Raft Foundation for the Building}

By using CROSS software, 3 bore holes were drawn in different places, with same properties, but different elevations of layers . According to the properties of the soil, the information below were used in each one:

Thickness of plate $=0.5 \mathrm{~m}$

The total load $=4000.64 \mathrm{kN}$

Total area of the plate foundation $347.8 \mathrm{~m}^{2}$ (first part)

Final stress that is applied in the area of pate $=16.14 \mathrm{ton} / \mathrm{m}^{2}$

Figure 5 and Table 1 list the soil properties of the site. 


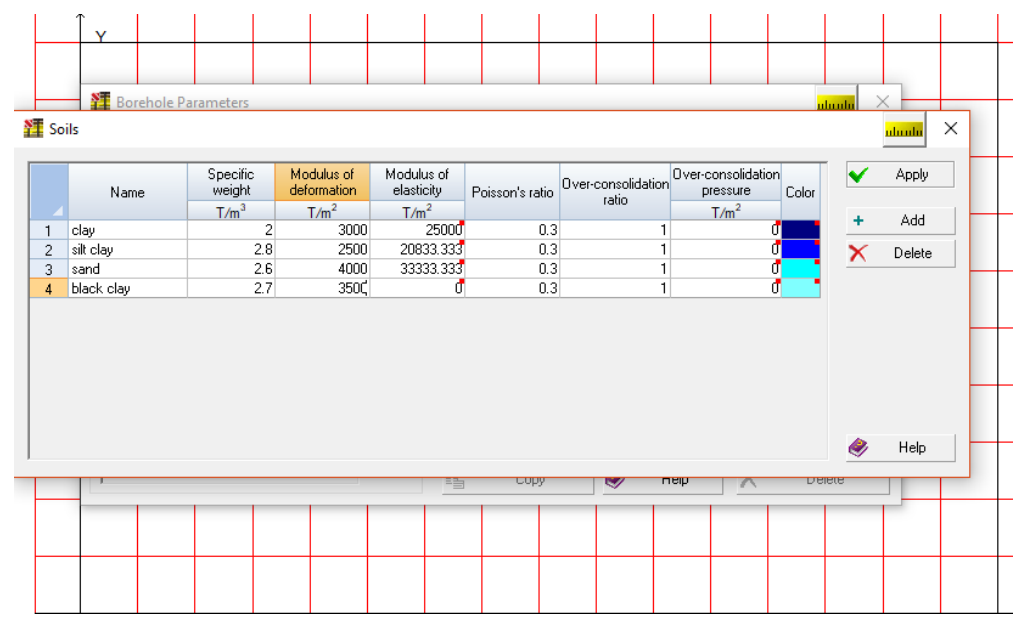

Fig. 5 Properties of the soil in cross office.

Table 1. Properties of soils in CROSS.

\begin{tabular}{|c|c|c|c|c|}
\hline $\begin{array}{c}\text { Soil } \\
\text { layer }\end{array}$ & $\begin{array}{c}\text { Specific } \\
\text { gravity }\end{array}$ & $\begin{array}{c}\text { Modulus of deformation } \\
\text { ton } / \mathrm{m}^{2}\end{array}$ & $\begin{array}{c}\text { Poissons } \\
\text { ratio }\end{array}$ & Over consolidation ratio \\
\hline 1 & 2 & 3000 & 0.3 & 1 \\
\hline 2 & 2.7 & 2500 & 0.3 & 1 \\
\hline 3 & 2.6 & 4000 & 0.3 & 1 \\
\hline 4 & 2.8 & 3500 & 0.3 & 1 \\
\hline
\end{tabular}

\section{Results}

By calculating the plate deformation in SCAD, Table 2 shows the total deformation obtained by the CROSS office. The distribution of settlement is illustrated in Figure 6, while Figure 7 shows the deformed shape of the foundation.

Table 2. Calculated total settelment in the building.

\begin{tabular}{|l|c|}
\hline Max settlement & $12 \mathrm{~cm}$ \\
\hline Min value of coefficient of elastic foundation & $328.346 \mathrm{ton} / \mathrm{m}^{3}$ \\
\hline Max value of coefficient of elastic foundation & $745.465 \mathrm{ton} / \mathrm{m}^{3}$ \\
\hline
\end{tabular}
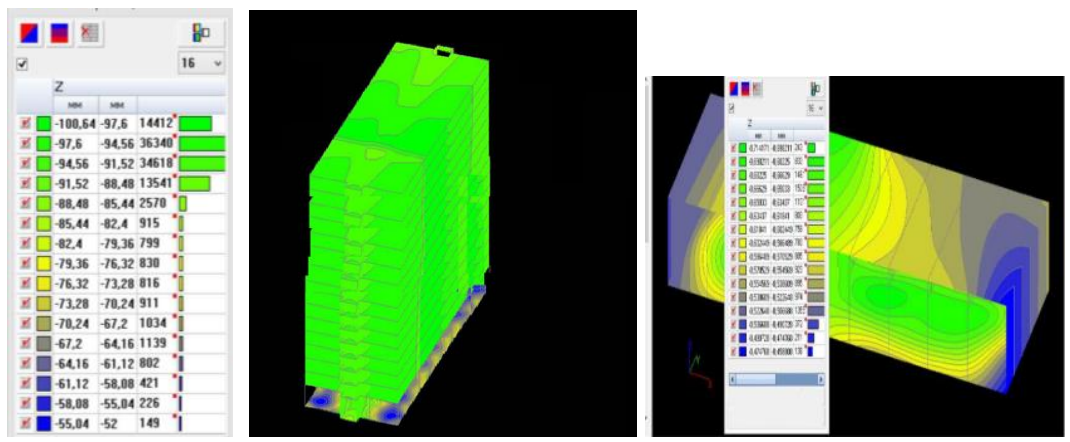

Fig. 6 Calculation the settlement of the first and the second part of the building. 

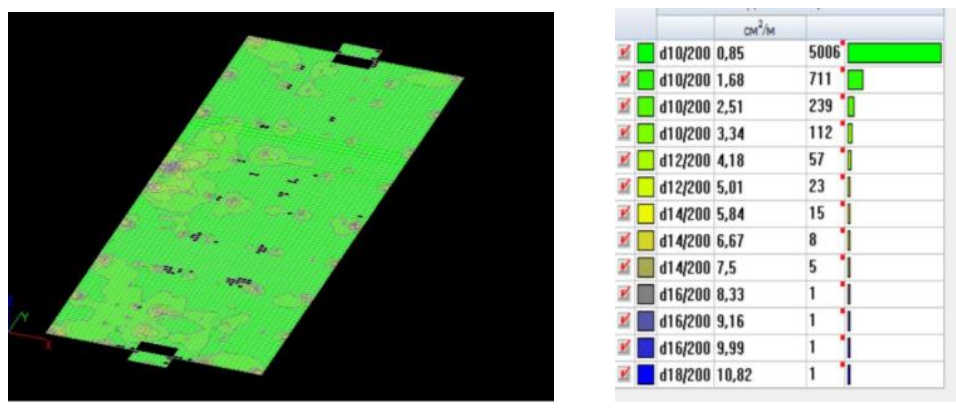

Fig. 7 Deformation of the foundation.

From the results of the SCAD office, it was found that the total settlement is $12 \mathrm{~cm}$ at the beginning of construction as compared to other value of the settlement in high-rise construction. It is shown that the value exceeds the limit which may cause a lot of problems in the future like oblique cracks along the whole building and destruction of it, so it will be a good idea if the soil of raft foundation is improved before constructing the building by using stone columns which are cheaper in comparison with piling.

\section{Application of Stone Columns}

Some portion of the total building load is transferred directly from the raft to the soil, therefore the load carried by columns is reduced and the number of columns could be minimized. The design of columns raft foundation requires an understanding of complex soil-structure interaction which affects on the load-settlement behavior (Katzenbach et al., 1997). To take into account this complicated interaction and to assess settlement of stone column, 3D FEM analysis is essential, which nowadays becomes readily available.

In the FEM analysis, 15-node wedge elements are used to model soils and volume columns as shown in Figure 8. The total number of elements was 16,603. Mohr-Columb model type was assumed for the stone column and undrained B for the soils below. Also medium deformation was restricted for mesh generation. Table 3 illustrates the material properties of the soil layers. Figure 9 shows the finite element mesh with deformed mesh. The stone columns used are $0.5 \mathrm{~m}$ in diameter and $20 \mathrm{~m}$ long.

Table 4. Subsoil's and material properties after Ilizar (Mirsayapov and Koroleva, 2016).

\begin{tabular}{|l|c|c|c|c|c|c|}
\hline \multicolumn{1}{|c|}{ Material } & Depth, $\mathrm{m}$ & $\begin{array}{c}\text { Young's } \\
\text { modulus } \\
\text { Eu }\end{array}$ & $\begin{array}{c}\text { Possion's } \\
\text { ratio }\end{array}$ & $\begin{array}{c}\text { Unit weight } \\
\left(\mathrm{kN} / \mathrm{m}^{3}\right)\end{array}$ & $\begin{array}{c}\text { Friction } \\
\text { angle } \\
(\text { degree })\end{array}$ & $\begin{array}{c}\text { Cohesion } \\
\left(\mathrm{kN} / \mathrm{m}^{2}\right)\end{array}$ \\
\hline Simi solid & -10 & 23000 & 0.49 & 19.6 & 23 & 26 \\
\hline Silt dense sand & -25 & 32000 & 0.3 & 20.3 & 22 & 15 \\
\hline $\begin{array}{l}\text { Sandy loam } \\
\text { semisolid }\end{array}$ & -30 & 22000 & 0.35 & 19.6 & 32 & 4 \\
\hline clay solid & -35 & 19000 & 0.49 & 17. & 0 & 86 \\
\hline Stones columns & -20 & $26.0 \times 106$ & 0.2 & 18 & 36 & 24 \\
\hline
\end{tabular}




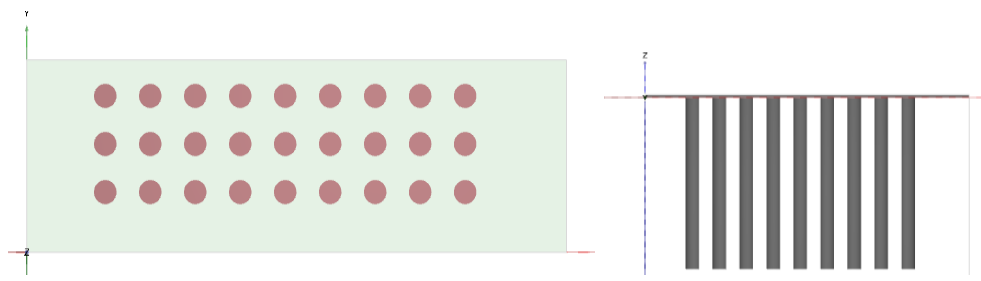

Fig. 8 Installation of stone column in Plaxis 3d.

\section{Numerical modeling of stone column and boundary conditions}

3D FEM via PLAXIS 3D Foundation was adopted for analysis of a high-rise building in Moscow Subsoil's. The building under consideration is a 20 -storey tall building with basements.
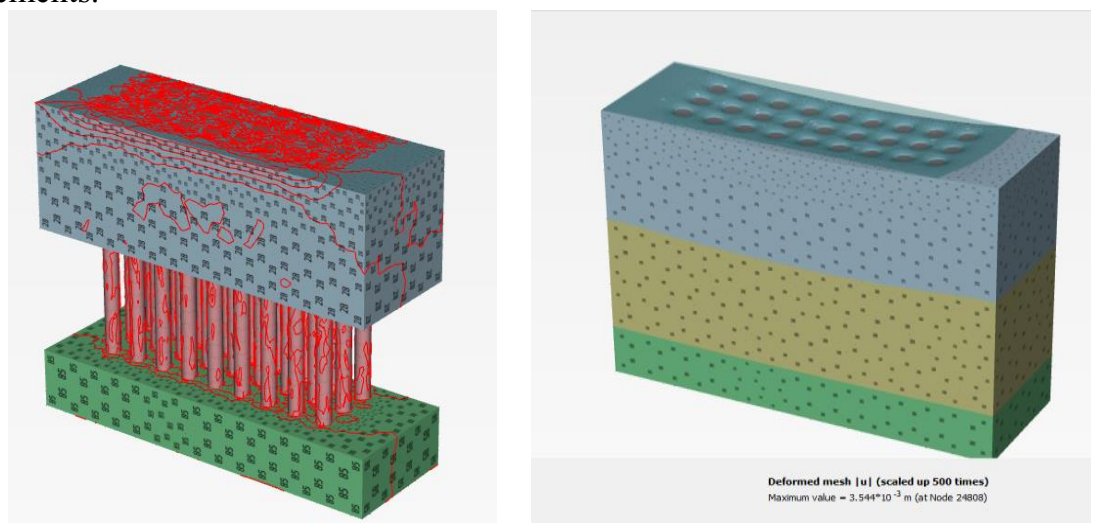

Fig. 9 Finite-element method discretization for stone column, typical deformed mesh.

As shown in Table 5 and Figure 10, the total settlement decreased by about $75 \%$ from the total settlement, when using stone columns as reinforcement material.

Shlash et al. (2009) concluded that when the shear strength of the soil decreases, the effect of stone column becomes more visible and a clear increase in $(\mathrm{q} / \mathrm{cu})$ ratio is noticed. Thus the effect of improvement seemed clearly in the treated soil of low shear strength. Therefore, it is expected that the stone column technique becomes more effective in very sot soils where the undrained shear strength of the clay is lower than $20 \mathrm{kPa}$.

Table 5 Compare the result between PLAXIS 3D and CROSS

\begin{tabular}{|c|c|}
\hline Settlement of Unimproved Foundation & $12 \mathrm{~cm}$ \\
\hline Settlement of Improved Foundation & $3 \mathrm{~cm}$ \\
\hline
\end{tabular}



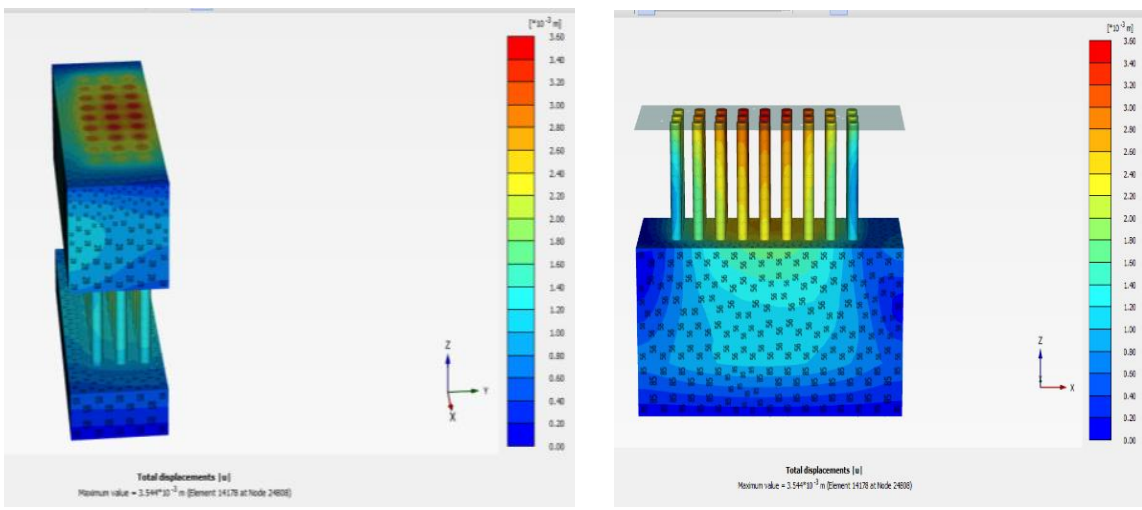

Fig. 10. Final 3D-finit element method deformation $($ settlement $=3 \mathrm{~cm})$.

\section{Conclusions}

Foundation base settlement was performed by numerical finite element methods of highrise construction building on the basis of the model to calculate the results of final settlement. The following conclusions were obtained:

1. The obtained results of settlement calculation of the high-rise building constructions on plate foundations are in good and agreement with the PLAXIS 3D of the ground base deformation, it is necessary to take into account the effect from the wall of the deep pit and the rigidity of the above ground structures.

2. The calculation can be done by using a software that implements the finite element method, allowing to create the structure dimensional model of buildings. This calculation model of the whole building includes the entire whole structure.

3. The total settlement decreased by about $75 \%$ from the total settlement, when using stone columns as reinforcement material.

\section{References}

1. M. Fattah, M. J. Al-Mosawi, A. A. O. Al-Zayadi Geomechanics and Engineering, 5(1), 17-36, Techno Press, Korea (2013)

2. M. Y. Fattah, M. A. Yousif, S. M. K. Al-Tameemi, Structural Engineering and Mechanics, an International Journal, Techno-Press Journals, Korea, 54(5) 829-853, (2015) DOI: $10.12989 / \mathrm{sem} .2015 .54 .5 .000$

3. R. Katzenbach, U. Arslan, J. Gutwald,, J. Holzhauser, H. Quick, Measurements and Numerical Studies. Proc. XIV ICSMFE, Balkema, 2, 1081-1084, (1997)

4. I.T. Mirsayapov and I.V. Koroleva, Journal The News of KSUAE, 2(16), 121-128 (2011)

5. I.T. Mirsayapov and I.V. Koroleva, Journal the News of KSUAE, 4(22), 193-198 (2012)

6. I.T. Mirsayapov and I.V. Koroleva, Soil Mechanics and Foundation Engineering Journal, 53(1), 5-11 (2016)

7. D.D.C. Nguyen,, S.B. Jo, D. S. Kim, Computers and Geotechnics, 47 (3), pp. 16-27 (2013)

8. T. Kais, Mohammed Y. Fattah, M. J. M. Al-Waily, Engineering and Technology Journal, University of Technology, Iraq, 27(9) 1673-1690 (2009) 